\title{
Evaluation of Factors Affecting Polyhydroxyalkanoates Production by Comamonas sp. EB172 Using Central Composite Design
}

\author{
Noor Azman Mohd Johar $^{1}$, Mohd Ali Hassan ${ }^{1,2}$, Mohd Rafein Zakaria ${ }^{1}$, Phang Lai Yee ${ }^{1}$, Yoshihito Shirai ${ }^{3}$ and \\ Hidayah Ariffin ${ }^{1 *}$ \\ ${ }^{1}$ Department of Bioprocess Technology, Faculty of Biotechnology and Biomolecular Sciences,Universiti Putra Malaysia, \\ 43400 Serdang, Selangor, Malaysia \\ ${ }^{2}$ Department of Process and Food Engineering, Faculty of Engineering, Universiti Putra Malaysia, 43400 Serdang, \\ Selangor, Malaysia \\ ${ }^{3}$ Department of Biological Functions and Engineering, Graduate School of Life Science and Systems Engineering, \\ Kyushu Institute of Technology, 2-4 Hibikino, Wakamatsu-ku, Kitakyushu, Fukuoka 808-0196, Japan \\ E.mail: hidayah a@biotech.upm.edu.my
}

Received 27 March 2012; Received in revised form 10 April 2012; Accepted 24 April 2012

\begin{abstract}
Aims: Statistical approach, central composite design (CCD) was used to investigate the complex interaction among temperature $\left(25-37{ }^{\circ} \mathrm{C}\right)$, initial medium $\mathrm{pH}(5-9)$, inoculum size $(4-10 \%(\mathrm{v} / \mathrm{v}))$, concentration of $\left(\mathrm{NH}_{4}\right)_{2} \mathrm{SO}_{4}(0-1 \mathrm{~g} / \mathrm{L})$ and concentration of mixed organic acids $(5-10 \mathrm{~g} / \mathrm{L})$ in the production of polyhydroxyalkanoates by Comamonas sp. EB172. Methodology and Results: Mixed organic acids derived from anaerobically treated palm oil mill effluent (POME) containing acetic:propionic:butyric (ratio of 3:1:1) were used as carbon source in the batch culture of Comamonas sp. EB172 to produce polyhydoxyalkanoates (PHAs). The analysis of variance (ANOVA) showed that all five factors were significantly important in the batch fermentation by shake flask with a $P$ value of less than 0.001 . The optimal temperature, initial medium $\mathrm{pH}$, inoculum size, concentration of $\left(\mathrm{NH}_{4}\right)_{2} \mathrm{SO}_{4}$ and concentration of mixed organic acids were $30{ }^{\circ} \mathrm{C}, 7.04,4.0 \%(\mathrm{v} / \mathrm{v}), 0.01 \mathrm{~g} / \mathrm{L}$ and $5.05 \mathrm{~g} / \mathrm{L}$ respectively.

Conclusion, significance and impact of study: Optimization of the production medium containing mixed organic acids has improved the PHA production for more than 2 folds. Under optimal condition in the shake flask fermentation, the predicted growth is $2.98 \mathrm{~g} / \mathrm{L}$ of dry cell weight (DCW) with 47.07 wt \% of PHA content. The highest yield of PHA was $0.28 \mathrm{~g}$ of PHA per $\mathrm{g}$ mixed organic acids.
\end{abstract}

Keywords: optimization, central composite design, Comamonas sp. EB172, polyhydroxyalkanoate, response surface methodology

\section{INTRODUCTION}

Studies on biodegradable plastics derived from microbes have been carried out for many years. However, the production cost is still a barrier to the use of biodegradable plastics, eg. polyhydroxyalkanoates (PHAs). Hence, the solution will lie upon low-cost options such as using cheaper carbon sources, efficient fermentation, and economical recovery process for PHA production (Grothe et al. 1999, Patwardhan et al. 2004). The cost for substrate may contribute $30-60 \%$ of the overall PHAs production cost (Zakaria et al. 2010a). Therefore, there have been several studies on the utilization of industrial by-producrs and agricultural wastes as alternative carbon sources for PHAs production (Hassan et al. 1997, Mumtaz et al. 2008). Utilization of biomass or renewable resource for PHAs production would be viable depending on the availability of the biomass and the technology involved in converting the complex materials into PHAs.

Palm oil mill effluent (POME) has been the most abundant and polluting agricultural wastewater in Malaysia (Alam et al. 2008). Hassan et al. (1997) studied on the production of organic acids from partial anaerobically treated POME, and it was revealed that the organic acids derived from POME could be use as carbon source for PHAs production by Rhodobacter sphaeroides. There were some other reports on the use of organic acids as substrate for PHA production by single and mixed culture (Chakraborty et al. 2009, Albuquerque et al. 2011). The feeding strategies of organic acids in the fermentation contributed to the variations of PHAs accumulation in the cell. Apart from feeding strategy, PHA accumulation can also be triggered under nutrient-limited conditions such as limited nitrogen, oxygen, sulphur, magnesium or phosphorus in the presence of excess carbon (Annuar et al. 2007; Sharma et al. 2007). Besides, the ration of carbon to nitrogen ( $\mathrm{C} / \mathrm{N}$ ratio) in medium formulation is an important factor with respect to the nutritional needs for both microbial biomass and PHA accumulation. . The effects of other factors such as temperature, initial medium $\mathrm{pH}$, inoculum size and concentration of $\left(\mathrm{NH}_{4}\right)_{2} \mathrm{SO}_{4}$ on PHAs production by using various types of 
microorganisms have been well studied (Sharma et al. 2007, Kemavongse et al. 2008, Mokhtari-Hosseini et al. 2009, Yang et al. 2010). Carbon sources such as sucrose (Grothe et al. 1999), glucose (Sharma et al. 2007), saponified palm kernel oil (Annuar et al. 2007) and methanol (Mokhtari-Hosseini et al. 2009) were also used to enhance PHAs production.

Recently, our group reported on the PHA production by Comamonas sp. EB172 utilizing mixed organic acids derived from POME. The strain accumulated PHAs up to 59 wt \% of DCW in fed batch cultivation (Zakaria et al. 2010a). However, the PHAs production by this strain from mixed organic acids was not optimized yet in batch fermentation. In the present study, we evaluate the factors affecting PHA production by Comamonas sp. EB172 with the use of statistical design. Preliminary screening was done by two-level factorial method. Two-level factorial design was used since it is possible to determine the influence of the multivariable factors and lessen the number of experiments by this method (Rasdi et al. 2009). Subsequently, the significant factors were optimized by using CCD whereby the experimental results were fitted with a second order polynomial equation in order to correlate the response variables to the independent variables.

\section{MATERIALS AND METHODS}

\section{Microorganism and Inoculums Preparation}

A locally isolated bacterium identified as Comamonas sp.EB172 was used in this study (Zakaria et al. 2010a). Enrichment medium used in this study was modified from Zakaria et al. (2010a), contained ( $\mathrm{g} / \mathrm{L}$ in distilled water): nutrient broth 8 ; yeast extract 5 ; peptone 5 ; and sodium acetate 5 . The $\mathrm{pH}$ was adjusted to $\mathrm{pH} 7.0$ by $2 \mathrm{M} \mathrm{NaOH}$. The strain was cultivated at $30^{\circ} \mathrm{C}$ and agitated at $200 \mathrm{rpm}$ until the $\mathrm{OD}_{600 \mathrm{~nm}}$ was more than 2.0. The cultures were then transferred into the production medium with $10 \%$ (v/v) inoculum.

\section{Production Medium}

In optimization study, the medium contained ( $\mathrm{g} / \mathrm{L}$ in distilled water) $\mathrm{KH}_{2} \mathrm{PO}_{4}, 5 ; \mathrm{K}_{2} \mathrm{HPO}_{4} 2$; $\mathrm{MgSO}_{4} .7 \mathrm{H}_{2} \mathrm{O} 0.4$; $\mathrm{CaCl}_{2} .2 \mathrm{H}_{2} \mathrm{O}$ 0.1; $\mathrm{FeSO}_{4} .7 \mathrm{H}_{2} \mathrm{O} 0.01$ and trace elements solution of $0.1 \mathrm{~mL}$ was used. The trace elements solution was prepared according to Hassan et al. (1997). Mixed organic acids derived from anaerobically treated POME with acid composition of acetatic:propionic:butyric at ratio $3: 1: 1$ as carbon source in the fermentation. The production of clarified organic acid was discussed elsewhere (Hassan et al. 1997; Mumtaz et al. 2008). $\left(\mathrm{NH}_{4}\right)_{2} \mathrm{SO}_{4}$ was used as the nitrogen source since it had been shown to be a suitable nitrogen source for bacterial growth and PHA production (Zakaria et al. 2008). Temperature, initial medium $\mathrm{pH}$, inoculum size, concentration of $\left(\mathrm{NH}_{4}\right)_{2} \mathrm{SO}_{4}$ and concentration of mixed organic acid were adjusted according to the experimental design protocols. The cells were cultivated for $36 \mathrm{~h}$ and agitated at $200 \mathrm{rpm}$ in $250 \mathrm{~mL}$ shake flask containing 50 $\mathrm{mL}$ of the medium described above. After fermentation, the cells were harvested by centrifugation at a speed $10,000 \mathrm{rpm}$ and freeze dried for further analysis.

\section{Analytical Method}

Cell growth was monitored by measuring the absorbance of the culture broth at $600 \mathrm{~nm}$ using a spectrophotometer (Hitachi, U-2900). Dry cell weight (DCW) was determined by standard plot between $\mathrm{OD}_{600 \mathrm{~nm}}$ and dry biomass. The organic acids concentration was analyzed by high performance liquid chromatography (HPLC) (Shimadzu, LC-10 AS) with Aminex 87H column (BIORAD, U.S.A) with $4 \mathrm{mM} \mathrm{H}_{2} \mathrm{SO}_{4}$ as mobile phase (Hassan et al. 1997). The PHA content of the biomass was determined by using gas chromatography (Agilent, 7890A) with benzoic acid as the internal standard by following the standard method (Braunegg et al. 1978).

\section{Statistical Design}

\section{Two level factorial design}

The two-level factorial design is a tool for this initial screening since it is possible to determine the influence of the multivariable factors and lessen the number of experiments (Rasdi et al. 2009). The variables tested were temperature, initial medium $\mathrm{pH}$, inoculum size, concentration of $\left(\mathrm{NH}_{4}\right)_{2} \mathrm{SO}_{4}$ and concentration of mixed organic acids. Table 1 shows the factors in the design and 20 experiments consisting of 16 runs and 4 center points were formulated for 5 factors using the software according to the $2^{5-1}$ fractional factorial design. Each factor was investigated at high $(+1)$ and low $(-1)$ levels. Concentration range for the variables was decided based on the reports for PHA production by Comamonas sp. EB172 (Zakaria et al. 2010a). The significances of the factors were identified by confidence level above $95 \%$ ( $P$ $<0.05$ ). Response was measured for the DCW and PHA content. Factors which gave $\mathrm{P}<0.05$ were selected for further studies.

\section{Response surface methodology (RSM)}

The optimal condition of growth and PHA production was investigated by statistical experiments using the Design Expert Software V7.0.0 (Stat-Ease Corporation, USA). The experiments were carried out according to the central composite design (CCD) (Table 2). A $2^{5}$-half fractional factorial central composite experimental design, ten axial points $(\alpha=2)$ and six replication of center points leading to a total number of 32 experiments was employed for the optimization of the factors (developed by design expert V7.0). The experimental results were fitted with a second order polynomial equation in order to correlate the response variables to the independent variables. This second order polynomial equation was obtained after the elimination of the insignificant parameters (Khanna et al. 
Table 1: Experimental design and responses of two-fractional factorial study

\begin{tabular}{|c|c|c|c|c|c|c|c|}
\hline \multirow[t]{2}{*}{ Expt. No. } & \multirow[t]{2}{*}{$\mathrm{X}_{1}\left({ }^{\circ} \mathrm{C}\right)$} & \multirow[t]{2}{*}{$\mathrm{X}_{2}$} & \multirow[t]{2}{*}{$\mathrm{X}_{3} \%(\mathrm{v} / \mathrm{v})$} & \multirow[t]{2}{*}{$\mathrm{X}_{4}(\mathrm{~g} / \mathrm{L})$} & \multirow[t]{2}{*}{$\mathrm{X}_{5}(\mathrm{~g} / \mathrm{L})$} & \multicolumn{2}{|c|}{ Response } \\
\hline & & & & & & $\mathrm{DCW} g / \mathrm{l}$ & PHA content $\%$ \\
\hline 1 & 25 & 5 & 4 & 1 & 5 & 0.412 & 2.16 \\
\hline 2 & 37 & 9 & 4 & 1 & 5 & 0.362 & 3.31 \\
\hline 3 & 37 & 5 & 4 & 0 & 5 & 0.417 & 9.10 \\
\hline 4 & 37 & 5 & 10 & 0 & 15 & 0.659 & 3.90 \\
\hline 5 & 37 & 9 & 4 & 0 & 15 & 0.264 & 5.30 \\
\hline 6 & 31 & 7 & 7 & 0.5 & 10 & 0.505 & 11.68 \\
\hline 7 & 25 & 5 & 10 & 0 & 5 & 0.634 & 3.79 \\
\hline 8 & 31 & 7 & 7 & 0.5 & 10 & 0.519 & 12.33 \\
\hline 9 & 25 & 9 & 10 & 0 & 15 & 0.514 & 5.00 \\
\hline 10 & 25 & 9 & 10 & 1 & 5 & 0.662 & 8.31 \\
\hline 11 & 25 & 5 & 4 & 0 & 15 & 0.443 & 2.50 \\
\hline 12 & 31 & 7 & 7 & 0.5 & 10 & 0.499 & 13.21 \\
\hline 13 & 25 & 9 & 4 & 0 & 5 & 0.387 & 3.80 \\
\hline 14 & 31 & 7 & 7 & 0.5 & 10 & 0.514 & 11.90 \\
\hline 15 & 25 & 5 & 10 & 1 & 15 & 0.647 & 4.00 \\
\hline 16 & 37 & 5 & 10 & 1 & 5 & 0.643 & 3.90 \\
\hline 17 & 37 & 9 & 10 & 1 & 15 & 0.501 & 7.19 \\
\hline 18 & 37 & 5 & 4 & 1 & 15 & 0.337 & 4.20 \\
\hline 19 & 37 & 9 & 10 & 0 & 5 & 0.503 & 13.32 \\
\hline 20 & 25 & 9 & 4 & 1 & 15 & 0.337 & 3.26 \\
\hline
\end{tabular}

$\mathrm{X}_{1}$ : temperature, $\mathrm{X}_{2}$ : initial medium $\mathrm{pH}, \mathrm{X}_{3}$ : inoculums size, $\mathrm{X}_{4}$ : concentration of $\left(\mathrm{NH}_{4}\right)_{2} \mathrm{SO}_{4}, \mathrm{X}_{5}$ : concentration of mixed organic acids

2005). Lack of fit obtained from the analysis will determine the significance of the model while student $t$-test will determine the significance of each parameter (Mrudula et al., 2011).

\section{RESULTS AND DISCUSSION}

\section{Two Level Factorial Design}

A screening process is necessary to determine the most influential factors affecting the cultivation process. The selection of factors involved in this screening process was based on previous studies reported by Zakaria et al. (2010a, 2010b) in which temperature, initial medium $\mathrm{pH}$, inoculum size, concentration of $\left(\mathrm{NH}_{4}\right)_{2} \mathrm{SO}_{4}$ and concentration of mixed organic acids were important parameters in regulating bacterial growth and PHA accumulation. The experimental range for each of the factors were as follows: temperature $\left(25-37{ }^{\circ} \mathrm{C}\right)$, initial medium $\mathrm{pH}$ (5-9), inoculum size (4-10 \% $\mathrm{v} / \mathrm{v})$, concentration of $\left(\mathrm{NH}_{4}\right)_{2} \mathrm{SO}_{4}(0-1 \mathrm{~g} / \mathrm{L})$ and concentration of mixed organic acids $(5-10 \mathrm{~g} / \mathrm{L})$. Table 1 shows the experimental design for 5 factors according to the Design Expert Software and the responses (DCW and PHA content). The patterns of response for low and high growth clearly corresponded to initial medium $\mathrm{pH}$ and inoculums size. From Table 1, runs 5, 13 and 19 showed that the growth and PHA production were inhibited at high initial $\mathrm{pH}$. This finding was supported by the results reported by Zakaria et al. (2010b) that Comamonas sp. EB172 could not grow and produce PHA at pH more than 8. Yang et al. (2010) reported that the growth of Ralstonia eutropha was inhibited in initial medium $\mathrm{pH}$ of more than
7.5. Besides, growth and PHA production were greatly affected by changes of temperature. Temperatures of 37 and $25{ }^{\circ} \mathrm{C}$ were not suitable for PHA production from Comamonas sp. EB172). As observed at the center point of the design (runs $6,8,12$, and 14), there was interaction between the concentration of $\left(\mathrm{NH}_{4}\right)_{2} \mathrm{SO}_{4}$ and other factors such as inoculums size, acid concentration and $\mathrm{pH}$. Apparently the growth of Comamonas sp. EB172 was affected by all the factors except for $\left(\mathrm{NH}_{4}\right)_{2} \mathrm{SO}_{4}$ concentration since the P-value for the $\left(\mathrm{NH}_{4}\right)_{2} \mathrm{SO}_{4}$ concentration was 0.1630 which was greater than 0.05 . In two level factorial design, an independent variable with $p$ value $>0.05$ can be taken as being not significant (Rasdi et al. 2009) and hence, it can be eliminated. However, $\mathrm{PHA}$ production was influence by $\left(\mathrm{NH}_{4}\right)_{2} \mathrm{SO}_{4}$ concentration as shown by analysis of variance with $\mathrm{P}$ value of 0.02 . Moreover, all of the other factors were significant since their $P$-values were $<0.05$. The screening of factors for growth and PHA production showed that all the factors were found to have significant effects and should be further investigated by using the central composite design (CCD) for optimization.

\section{Central Composite Design (CCD)}

Based on the screening test of variables by the twofractional factorial design, all five variables mentioned above were set in the ranges as shown in Table 2. Comamonas sp. EB172 was found to be an effective PHA producer by using mixed organic acids as carbon source. Comamonas sp. EB172 was identified as a growthassociated bacteria which produce PHA during their growth. One-step cultivation was used in this experiment. 
Table 2: The experimental design and results for the cell dry weight and PHAs production for the central composite design (CCD)

\begin{tabular}{|c|c|c|c|c|c|c|c|c|c|}
\hline \multirow[b]{2}{*}{ Run } & \multirow[b]{2}{*}{$\mathrm{X}_{1}\left({ }^{\circ} \mathrm{C}\right)$} & \multirow[b]{2}{*}{$X_{2}$} & \multirow[b]{2}{*}{$\mathrm{X}_{3}(\% \mathrm{v} / \mathrm{v})$} & \multirow[b]{2}{*}{$\begin{array}{c}\mathrm{X}_{4} \\
(\mathrm{~g} / \mathrm{L})\end{array}$} & \multirow[b]{2}{*}{$\begin{array}{c}\mathrm{X}_{5} \\
(\mathrm{~g} / \mathrm{L})\end{array}$} & \multicolumn{2}{|c|}{ Experimental } & \multicolumn{2}{|c|}{ Predicted } \\
\hline & & & & & & $\begin{array}{r}\text { DCW } \\
(\mathrm{g} / \mathrm{L})\end{array}$ & $\begin{array}{l}\text { PHA content } \\
\text { (wt. \%) }\end{array}$ & $\begin{array}{l}\text { DCW } \\
(\mathrm{g} / \mathrm{L})\end{array}$ & $\begin{array}{l}\text { PHA content } \\
\text { (wt. \%) }\end{array}$ \\
\hline 1 & 34 & 8 & 5.5 & 0.25 & 8.75 & 3.14 & 29.98 & 1.91 & 36.93 \\
\hline 2 & 28 & 6 & 5.5 & 0.75 & 6.25 & 2.55 & 5.77 & 0.97 & 4.17 \\
\hline 3 & 31 & 7 & 7 & 0.5 & 7.5 & 4.2 & 34.5 & 3.98 & 27.70 \\
\hline 4 & 31 & 7 & 7 & 0.5 & 7.5 & 4.98 & 24.66 & 3.98 & 27.70 \\
\hline 5 & 34 & 6 & 8.5 & 0.75 & 6.25 & 3.92 & 21.11 & 2.68 & 14.96 \\
\hline 6 & 28 & 8 & 8.5 & 0.75 & 6.25 & 7.88 & 15.94 & 5.80 & 16.57 \\
\hline 7 & 34 & 6 & 8.5 & 0.25 & 8.75 & 2.67 & 18.75 & 1.81 & 20.11 \\
\hline 8 & 31 & 7 & 7 & 1 & 7.5 & 6.98 & 10.75 & 3.98 & 19.97 \\
\hline 9 & 25 & 7 & 7 & 0.5 & 7.5 & 3.92 & 1.55 & 2.29 & 0.38 \\
\hline 10 & 34 & 6 & 5.5 & 0.75 & 8.75 & 2.75 & 34.44 & 1.12 & 30.33 \\
\hline 11 & 28 & 8 & 5.5 & 0.75 & 8.75 & 6.33 & 1.48 & 4.24 & 3.66 \\
\hline 12 & 31 & 7 & 7 & 0.5 & 5 & 4.71 & 38.76 & 3.50 & 37.52 \\
\hline 13 & 37 & 7 & 7 & 0.5 & 7.5 & 1 & 20.44 & 0.98 & 27.10 \\
\hline 14 & 31 & 7 & 4 & 0.5 & 7.5 & 4.35 & 28.51 & 3.28 & 34.42 \\
\hline 15 & 28 & 8 & 5.5 & 0.25 & 6.25 & 4.02 & 15.32 & 5.11 & 18.11 \\
\hline 16 & 31 & 9 & 7 & 0.5 & 7.5 & 4.82 & 9.66 & 4.71 & 6.07 \\
\hline 17 & 31 & 7 & 7 & 0.5 & 7.5 & 5.3 & 41.6 & 3.98 & 27.70 \\
\hline 18 & 28 & 6 & 8.5 & 0.25 & 6.25 & 2.19 & 9.98 & 1.66 & 11.86 \\
\hline 19 & 31 & 7 & 7 & 0 & 7.5 & 4.33 & 44.81 & 3.98 & 36.68 \\
\hline 20 & 28 & 6 & 8.5 & 0.75 & 8.75 & 1.07 & 1.44 & 0.80 & 1.21 \\
\hline 21 & 28 & 8 & 8.5 & 0.25 & 8.75 & 6.3 & 9.55 & 4.94 & 11.00 \\
\hline 22 & 28 & 6 & 5.5 & 0.25 & 8.75 & 0.72 & 1.3 & 0.10 & 1.66 \\
\hline 23 & 31 & 7 & 10 & 0.5 & 7.5 & 5.53 & 14.55 & 4.67 & 21.70 \\
\hline 24 & 34 & 8 & 8.5 & 0.25 & 6.25 & 4.63 & 15.63 & 3.47 & 19.69 \\
\hline 25 & 31 & 5 & 7 & 0.5 & 7.5 & 1.31 & 0.32 & 0.23 & 1.61 \\
\hline 26 & 31 & 7 & 7 & 0.5 & 7.5 & 4.17 & 22.2 & 3.98 & 27.70 \\
\hline 27 & 34 & 6 & 5.5 & 0.25 & 6.25 & 2.88 & 47.05 & 1.98 & 41.97 \\
\hline 28 & 31 & 7 & 7 & 0.5 & 7.5 & 4.98 & 28.7 & 3.98 & 27.70 \\
\hline 29 & 34 & 8 & 5.5 & 0.75 & 6.25 & 4.67 & 33.38 & 2.77 & 29.82 \\
\hline 30 & 34 & 8 & 8.5 & 0.75 & 8.75 & 4.37 & 17.44 & 2.61 & 12.02 \\
\hline 31 & 31 & 7 & 7 & 0.5 & 7.5 & 4.85 & 25.92 & 3.98 & 27.70 \\
\hline 32 & 31 & 7 & 7 & 0.5 & 10 & 2.22 & 26.45 & 1.78 & 19.36 \\
\hline
\end{tabular}

$\mathrm{X}_{1}$ : temperature, $\mathrm{X}_{2}$ : initial medium $\mathrm{pH}, \mathrm{X}_{3}$ : inoculums size, $\mathrm{X}_{4}$ : concentration of $\left(\mathrm{NH}_{4}\right)_{2} \mathrm{SO}_{4}, \mathrm{X}_{5}$ : concentration of mixed organic acids

Table 3: Summary of model terms for growth of and PHAs production Comamonas sp. Eb172

\begin{tabular}{lcc} 
& \multirow{2}{*}{ Terms } & \multicolumn{2}{c}{ P-value } \\
\cline { 2 - 3 } & CDW & PHA content \\
\hline$X_{1}$ & 0.0430 & $<0.0001$ \\
$X_{2}$ & $<0.0001$ & 0.0501 \\
$X_{3}$ & 0.0331 & 0.0477 \\
$X_{4}$ & 0.0029 & 0.0113 \\
$X_{5}$ & 0.0097 & 0.0067 \\
$X_{1} X_{2}$ & 0.0002 & 0.0285 \\
$X_{1} X_{3}$ & $-{ }^{*}$ & 0.0023 \\
$X_{1} X_{4}$ & 0.0003 & 0.0634 \\
$X_{1}{ }^{2}$ & 0.0045 & 0.0002 \\
$X_{2}{ }^{2}$ & 0.0233 & $<0.0001$ \\
$X_{4}{ }^{2}$ & $>0.05$ were eliminated in CCD
\end{tabular}

Table 2 shows that the highest DCW was achieved $(7.88$ $\mathrm{g} / \mathrm{L})$ on run no. 6 , with $0.75 \mathrm{~g} / \mathrm{L}$ of $\left(\mathrm{NH}_{4}\right)_{2} \mathrm{SO}_{4}$ contributing to low PHA accumulation (15.94 wt.\%). On the other hand, it could be seen that PHA accumulation was triggered by nitrogen limitation as seen on run no. 27 , 47.05 wt \% of PHA content was achieved with slightly low DCW $(2.88 \mathrm{~g} / \mathrm{L})$. $\left(\mathrm{NH}_{4}\right)_{2} \mathrm{SO}_{4}$ concentration played an important role in DCW and PHA accumulation. This was comparable with the study of Annuar et al. (2007) who reported that Pseudomonas putida needed nitrogen limitation for PHA accumulation. As shown in Table 3, the $\mathrm{P}$-value of $\left(\mathrm{NH}_{4}\right)_{2} \mathrm{SO}_{4}$ concentration for growth was 0.0029 and for PHA accumulation at was 0.0113. P-value lower than $0.05(P<0.05)$ indicated high influence of the factors to the response. The results also showed that initial medium $\mathrm{pH}$ was important for bacterial growth and PHA production with P-values $<0.0001$ and 0.0501 respectively. This finding was supported by Zakaria et al (2010b) who reported that increasing the initial medium $\mathrm{pH}(6.5-8)$ would increase the biomass and reduce the PHA production. We found that, initial medium $\mathrm{pH} 7$ was the best condition for both responses. 
Table 4: Analysis of variance (ANOVA): a) for the growth of Comamonas sp. EB172, b) for the PHAs production by Comamonas sp. EB172.

\begin{tabular}{|c|c|c|c|c|c|c|}
\hline \multirow[t]{9}{*}{ a. } & Source & $\begin{array}{l}\text { Sum of } \\
\text { Squares }\end{array}$ & $\begin{array}{l}\text { Degree of } \\
\text { freedom }\end{array}$ & Mean Square & F-Value & Prob $>\mathrm{F}$ \\
\hline & Model & 80.9484 & 9 & 8.9943 & 16.0849 & $<0.0001$ \\
\hline & Residual & 12.3018 & 22 & 0.5592 & & \\
\hline & Lack of Fit & 11.2447 & 17 & 0.6615 & 3.1285 & 0.1057 \\
\hline & Pure Error & 1.0571 & 5 & 0.2114 & & \\
\hline & Cor Total & 93.2503 & 31 & & & \\
\hline & $\begin{array}{l}\text { Coefficient of correlation } \\
\left(R^{2}\right)\end{array}$ & & & 0.8681 & & \\
\hline & $\begin{array}{l}\text { Coefficient of } \\
\text { determination }\end{array}$ & & & 0.8141 & & \\
\hline & Coefficient of variation & & & 18.7325 & & \\
\hline \multirow[t]{9}{*}{ b. } & Source & $\begin{array}{l}\text { Sum of } \\
\text { Square }\end{array}$ & $\begin{array}{l}\text { Degree of } \\
\text { freedom }\end{array}$ & Mean squares & F-value & Prob $>F$ \\
\hline & Model & 84.4244 & 10 & 8.4424 & 17.2424 & $<0.0001$ \\
\hline & Residual & 10.2823 & 21 & 0.4896 & & \\
\hline & Lack of Fit & 8.1968 & 16 & 0.5123 & 1.2282 & 0.4432 \\
\hline & Pure Error & 2.0855 & 5 & 0.4171 & & \\
\hline & Cor Total & 94.7066 & 31 & & & \\
\hline & $\begin{array}{l}\text { Coefficient of correlation } \\
\left(R^{2}\right)\end{array}$ & & & 0.8914 & & \\
\hline & $\begin{array}{l}\text { Coefficient of } \\
\text { determination }\end{array}$ & & & 0.8397 & & \\
\hline & Coefficient of variation & & & 16.7684 & & \\
\hline
\end{tabular}

The mathematical models for the DCW (Eq. (1)) and PHA (Eq. (2)) content in response to the process variables are given by:

$$
\begin{aligned}
& Y_{D C W}=-156.8+5.88 X_{1}+15.98 X_{2}+0.23 X_{3}+2.87 X_{5}-0.28 X_{1} X_{2}-0.07 X_{1}^{2} \\
& -0.43 X_{2}^{2}-0.21 X_{5}^{2} \\
& \sqrt{Y_{P H A}}=-145.99+5.65 X_{1}+16.44 X_{2}+3.97 X_{3}-1.59 X_{4}-3.18 X_{5} \\
& -0.14 X_{1} X_{2}-0.14 X_{1} X_{3}+0.09 X_{1} X_{5}-0.07 X_{1}^{2}-0.85 X_{2}^{2}
\end{aligned}
$$

Where $Y_{\mathrm{DCW}}$ is the dry cell weight $(\mathrm{g} / \mathrm{L})$ and $\sqrt{Y_{P H A}}$ is the PHA content (wt. \%). $X_{1}, X_{2}, X_{3}, X_{4}$ and $X_{5}$ are the variables for temperature $\left({ }^{\circ} \mathrm{C}\right)$, initial medium $\mathrm{pH}$, inoculum size $(\% \mathrm{v} / \mathrm{v})$, concentration of $\left(\mathrm{NH}_{4}\right)_{2} \mathrm{SO}_{4}(\mathrm{~g} / \mathrm{L})$ and concentration of mixed organic acids $(\mathrm{g} / \mathrm{L})$ respectively.

The P-values for the model are shown in Table 3. Nonsignificant terms with $\mathrm{P}$-values of more than 0.05 were eliminated such as the interaction of temperature with inoculums size and temperature with concentration of $\left(\mathrm{NH}_{4}\right)_{2} \mathrm{SO}_{4}(\mathrm{~g} / \mathrm{L})$ and as a result an equation (1) was generated. The main and quadratic effect (interaction) mentioned in Table 3 with $p$-value $<0.05$ were the most important in the growth of the Comamonas sp. EB172. A summary of the analysis of variance (ANOVA) for the model $Y_{D C W}$ is presented in Table 4. Data of the experiments were fitted to the model and supported by the multiple correlation coefficients $\left(R^{2}\right)$ and the correlation of determination (adjusted $R^{2}$ ). Adjusted $R^{2}$ at 0.87 indicated that $87 \%$ of the sample variation for the DCW was attributed to independent variables (Table 4a). This means that the model is significant. A large value of $F$ indicates more variance as explained by the model.

The Box Cox plot was used to determine the appropriate power transformation in PHA production (Davenport and Curtis, 2008). The model for PHA production was implemented with square root equation as shown in equation (2). The coefficient of determination $\left(R^{2}=0.89\right)$ showed that $89 \%$ of the variability in the response could be explained by the model and demonstrates that the model was significant for PHA production (Table 4b). All the main effects for PHA production were significant. The initial medium $\mathrm{pH}$ was found to have the least effect compared to the other factors. Three interaction between the factors with $P$-values $<0.05$ were selected to be analysed in the 3D surface graph to determine the optimal value.

Figure 1 shows the 3D surface graph of the model. The results of further analyses on two-factor interaction effects showed that growth was significantly increased 
a)

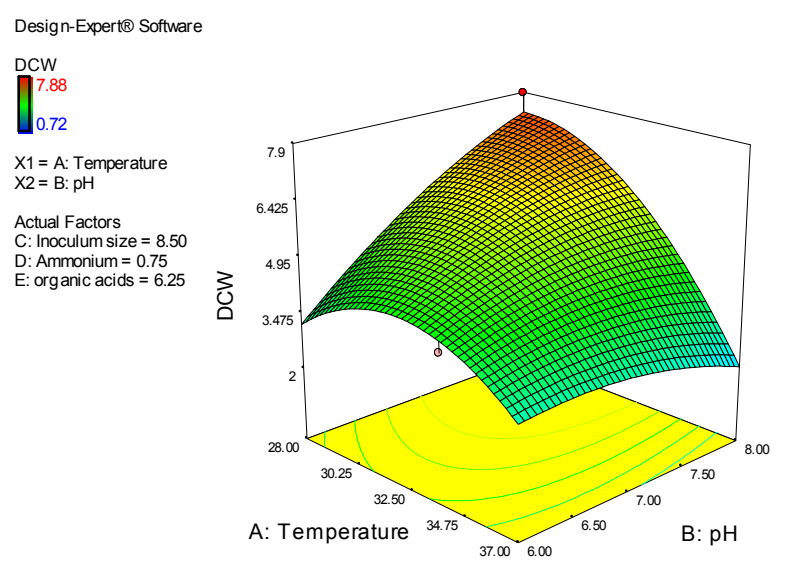

c)

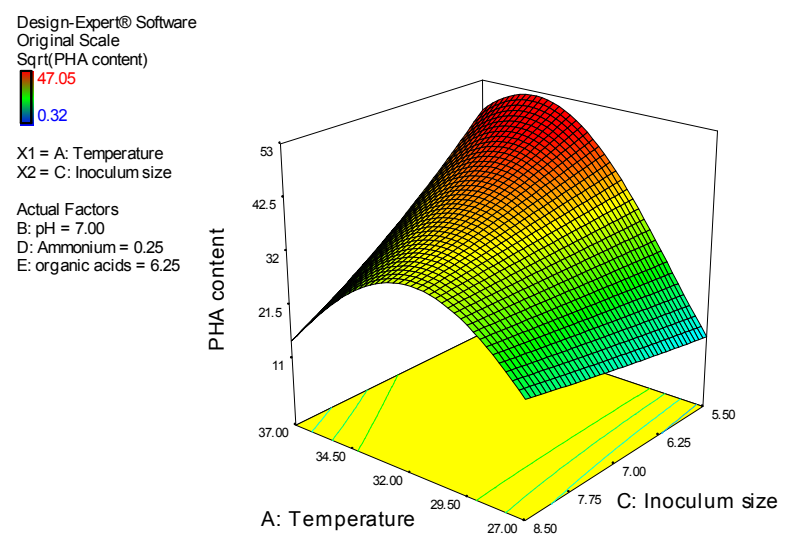

b)

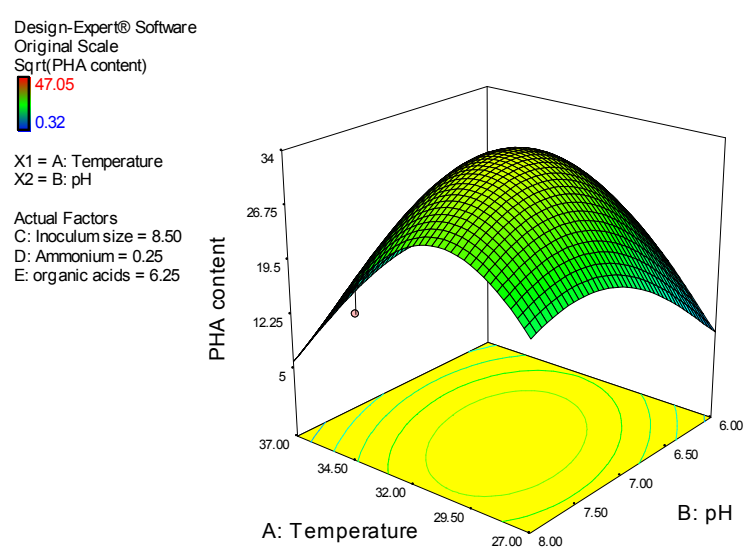

d)

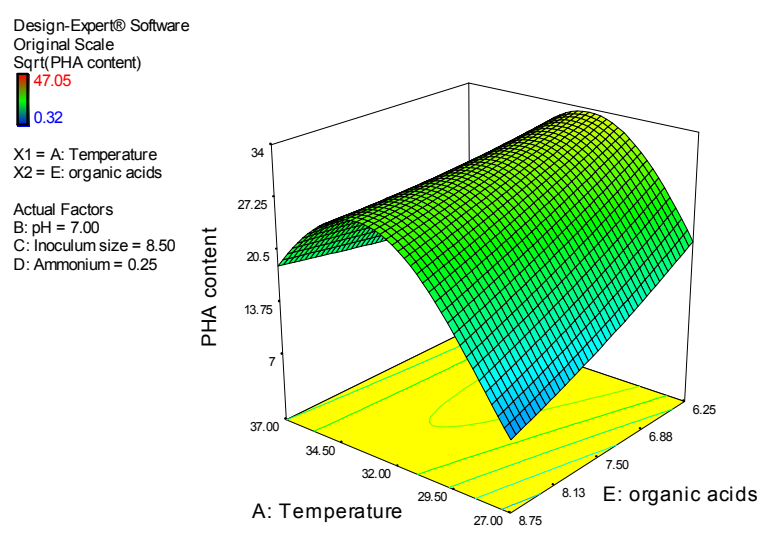

Figure 1: Three dimensional surface graph of the model A) for DCW with interaction of temperature and initial medium $\mathrm{pH}, \mathrm{b})$ temperature and initial medium $\mathrm{pH}, \mathrm{c}$ ) temperature and inoculum size and d) temperature and concentration of mixed organic acids.

$(\mathrm{P}=0.0002)$ by interactions of temperature with $\mathrm{pH}$ as shown in Figure 1a. There wassignificant increase in the growth of Comamonas sp. EB172 at temperature $30{ }^{\circ} \mathrm{C}$ and $\left(\mathrm{NH}_{4}\right)_{2} \mathrm{SO}_{4}$ concentration of $0.75 \mathrm{~g} / \mathrm{L}$ as the initial medium $\mathrm{pH}$ increased. This can be explained when the maximum predicted value is indicated by the surface confined in the smallest ellipse in the graph (Alam et al. 2008). However, PHA accumulation was inhibited at $\mathrm{pH}$ more than 7.5 (Figure 1b). Two-factor interaction effects also showed that PHA accumulation increased by interaction of inoculums size with temperature $(P=0.0023)$ and mixed organic acids with temperature $(P=0.0634)$ (Figure 1c, d). The maximumcell growth $(5.14 \mathrm{~g} / \mathrm{L})$ was recorded at temperature $30^{\circ} \mathrm{C}$; initial medium $\mathrm{pH}$ of $\mathrm{pH}$ 7.99; inoculum size of $7.06 \%(\mathrm{v} / \mathrm{v}) ; \quad\left(\mathrm{NH}_{4}\right)_{2} \mathrm{SO}_{4}$ concentration of $0.52 \mathrm{~g} / \mathrm{L}$ and mixed organic acids concentration of $9.04 \mathrm{~g} / \mathrm{L}$. The optimal values for temperature, initial medium $\mathrm{pH}$, inoculum size, concentration of $\left(\mathrm{NH}_{4}\right)_{2} \mathrm{SO}_{4}$ and concentration of organic acids was $30{ }^{\circ} \mathrm{C}, 7.04,0.01 \mathrm{~g} / \mathrm{L}, 4.0 \% \mathrm{v} / \mathrm{v}$ and $5.05 \mathrm{~g} / \mathrm{L}$ respectively when both response were considered. The predicted maximum growth of Comamonas sp. EB172 was $2.98 \mathrm{~g} / \mathrm{L}$ and the maximum PHA content was 47.1 wt. $\%$ of the DCW in the shake flasks study.

\section{CONCLUSION}

Medium composition was optimized by statistical design for bacterial growth and PHA production by Comamonas sp. EB172 from mixed organic acids derived from anaerobically treated POME. The mathematical model generated from the CCD for growth and PHA production had high correlation coefficient $\left(R^{2}\right), \quad 0.87$ and 0.89 respectively after screening and optimization by RSM. The optimized conditions included temperature, initial medium $\mathrm{pH}$, inoculum size, concentration of $\left(\mathrm{NH}_{4}\right)_{2} \mathrm{SO}_{4}$ and concentration of organic acids of $30^{\circ} \mathrm{C}, 7.04,0.01 \mathrm{~g} / \mathrm{L}, 4.0$ $\% \mathrm{v} / \mathrm{v}$ and $5.05 \mathrm{~g} / \mathrm{L}$ respectively. In further investigation, the development of a mathematical model for batch fermentation and simulation of fed batch 
fermentation in a bioreactor should be done.

\section{ACKNOWLEDGMENTS}

The authors would like to thank the Federal Land Development Authority Malaysia (FELDA), Malaysia, Ministry of Science Technology and Innovation (MOSTI), Malaysia and the Japan Society for Promotion of Science (JSPS) for funding and technical support throughout the study.

\section{REFERENCES}

Alam, M.Z., Jamal, P., Nadzir, M.M. (2008). Bioconversion of palm oil mill effluent for citric acid production: statistical optimization of fermentation media and time by central composite design. World Journal of Microbiology and Biotechnology 24:11771185

Albuquerque, M.G.E., Martino, V., Pollet, E., Averous, L., Reis, M.A.M. (2011). Mixed culture polyhydroxyalkanoate (PHA) production from volatile fatty acid (VFA)-rich stream: effect of substrate composition and feeding regime on PHA productivity, composition and properties. Journal of Biotechnology 151:66-76

Annuar, M.S.M., Tan, I.K.P., Ibrahim, S., Ramachandran, K.B. (2007). Production of medium carbon length polyhydroxyalkanoate from crude fatty acids mixture by Pseudomona putida. Food and Bioproducts Processing 85:104-119

Braunegg, G., Sonnleitner, B., Lafferty, R.M. (1978). A rapid gas chromatographic method for the determination of poly- $\beta$-hydroxybutyric acid in microbial biomass. European Journal of Application and Microbiology 6:29 37

Chakraborty, P., Gibbons, W., Muthukumarappan, K. (2009). Conversion of volatile fatty acids into polyhydroxyalkanoates by Ralstonia eutropha. Journal of Application and Microbiology 106:19962005

Davenport, R.J., Curtis, T.P. (2008). Quantitative fluorescence in situ hybridisation (FISH): statistical methods for valid cell counting. Molecular Microbial Ecology Manual 2nd Edition 7.07:1487-1516

Grothe, E., Murray, M.Y., Chisti, Y. (1999). Optimization for the production of polyhydroxybutyric acid microbial thermoplastic. Enzyme Microbiology and Technology 25:132-141

Hassan, M.A., Shirai, Y., Kusubayashi, N., Abdul Karim, M.I., Nakanishi, K., Hashimoto, K. (1997). Effect of organic acids profiles during anaerobic treatment of palm oil mill effluent on the production of polyhydroxyalkanoate by Rhodobacter Sphaeroides. Journal of Fermentation and Bioengineering 82:151156

Kemavongse, K., Presertsan, P. (2008). Poly- $\beta-$ hydroxyalkanoate production by halotolerant Rhodobacter sphaeroides U7. World Journal of Microbiology and Biotechnology 24:2073-2085

Khanna, S. and Srivastava, AK. (2005). Statistical media optimization studies for growth and PHB production by Ralstonia eutropha. Process Biochemistry 40:2173-2182

Mokhtari-Hosseini, Z.B., Vashegahani-Farahani, E., Heidazardeh-Vazifekhoran, A., Shojaosadati, S.A., Karimzadeh, R., Darani, K.K. (2009). Statistical media optimization for growth and PHB production from methanol by a methylotrophic bacterium. Bioresource Technology 100:2436-2443

Mumtaz, T., Abd-Aziz, S., Nor'Aini, A.R., Phang, L.Y., Shirai, Y., Hassan, M.A. (2008). Pilot-scale recovery of low molecular weight organic acids from anaerobically treated palm oil mill effluent (POME) with energy integrated system. African Journal of Biotechnology 7:3900-3905

Mrudula, S., Gopal, R., Seenayya, G. (2011). Optimization of medium components using response surface methodology for production of thermostable amylopullulanase in submerged fermentation by Clostridium thermosulfurogenes SVM17. Malaysian Journal of Microbiology 7(4):181-191

Patwardhan, P.R., Srivastava, A.K. (2004). Model-based fed-batch cultivation of Ralstonia eutropha for enhanced biopolymer production. Biochemistry Engineering Journal 20:21-28

Rasdi, Z., Nor'Aini, A.R., Abd-Aziz, S., Phang, L.Y., Yusoff, M.Z.M., Chong, M.L., Hassan, M.A. (2009). Statistical optimization of biohydrogen production from palm oil mill effluent by natural microflora. The Open Biotechnology Journal 3:79-86

Sharma, L., Singh, A.K., Panda, B., Mallick, N. (2007). Process optimization for polyhydroxyalkanoate production in a nitrogen fixing cyanobacterium, Nostoc muscorum using response surface methodology. Bioresource Technology 98: 987-993

Yang, Y.H., Brigham, C.J., Budde, C.F., Boccazzi, P., Willis, L.B., Hassan, M.A., Yusof, Z.A.M., Rha, C.K., Sinsckey, A.J. (2010). Optimization of growth media components for polyhydroxyalkanoate (PHA) production from organic acids by Ralstonia eutropha. Application Microbiology and Biotechnology 87: 2037 2045

Zakaria, M.R., Abd-Aziz, S., Ariffin, H., Nor'Aini, A.R., Phang, L.Y., Hassan, M.A. (2008). Comamonas sp. EB172 isolated from digester treating palm oil mill effluent as potential polyhydroxyalkanoate (PHA) producer. African Journal of Biotechnology 7: 41184121

Zakaria, M.R., Ariffin, H., Johar, N.A.M., Abd-Aziz, S., Nishida, H., Shirai, Y., Hassan, M.A. (2010a). Biosynthesis and characterization of poly (3hydroxybutyrate-co-3-hydroxyvalerate) copolymer from wild-type Comamonas sp. EB172. Polymer Degradation and Stability 95:1382-1386

Zakaria, M.R., Tabatabaei, M., Farinazleen, M.G., AbdAziz, S., Shirai, Y., Hassan, M.A. (2010b). Polyhydroxyalkanoate production from anaerobically treated palm oil mill effluent by new bacterial strain Comamonas sp. EB172. World Journal of Microbiology and Biotechnology 26:767-774 